Accepted version of Scottish Journal of Geology, Volume 54 (2), 77-86.

\title{
On the age of the Ballantrae Complex, SW Scotland
}

\section{Philip Stone $^{1^{*}}$ \& Adrian W. A. Rushton ${ }^{2}$}

1. British Geological Survey, The Lyell Centre, Research Avenue South, Edinburgh EH14 4AP.

2. Department of Earth Sciences, The Natural History Museum, Cromwell Road, London SW7 5BD.

*Corresponding author (e-mail: psto@bgs.ac.uk)

Running Head: On the age of the Ballantrae Complex

\begin{abstract}
The Ballantrae Complex, SW Scotland, is an ophiolitic assemblage of mostly Early and early Middle Ordovician age (Tremadoc - Arenig in terms of the British Ordovician Series). Its varied components were generated and assembled in the Iapetus Ocean, then obducted onto the Laurentian continental margin by the earliest Llanvirn. The timing of obduction is constrained by biostratigraphic and radiometric data. It was most probably a polyphase process initiated at about the beginning of the Arenig, at about 478 Ma. However, parts of the Complex are significantly younger, with some recent evidence taken to suggest an earliest Llanvirn age of about $464 \mathrm{Ma}$ for the emplacement of some of the volcanic and pelagic sedimentary rocks. The oldest strata in the succession that now unconformably overlies the Ballantrae Complex were deposited at about 463 Ma. Hence there may have been as little as one million years available for the final stages of the Complex's tectonic assembly, obduction, uplift, erosion and downfaulting. Obduction of the Complex has been invoked as a factor in the initiation of the Grampian Orogeny, and whilst there is a broad correlation in timing, the detail from Ballantrae militates against a causal relationship.
\end{abstract}

\section{Introduction}

The Scottish-Irish sector of the Caledonian Orogen contains several broadly ophiolitic, structural inliers within the tectonic boundary zone separating the Midland 
Valley Terrane from the Southern Uplands-Down-Longford Terrane. The ophiolitic rocks, mostly of Late Cambrian to Middle Ordovician age, were derived from a variety of oceanic environments - island arc, within-plate and/or mid-ocean ridge and are generally believed to have been accreted or obducted at the Laurentian continental margin as the Iapetus Ocean began to close late in the Early Ordovician. In Scotland, the Midland Valley Terrane includes several inliers that contain lower Palaeozoic rocks, but only in the Girvan-Ballantrae district of south-west Scotland does the succession extend below the Silurian and overlie an ophiolitic basement, the Ballantrae Complex.

The obduction of the Ballantrae Complex onto the margin of Laurentia has been widely linked with initiation of the Grampian Orogeny (or Grampian phase of the Caledonian Orogeny) (e.g. Bluck et al. 1980; Oliver et al. 2000; Stewart et al. 2017), which is itself thought to have been a relatively short-lived tectonic episode, peaking during the Arenig and spanning no more than about 15 million years: e.g. 480-465 Ma (Oliver 2001), 475-465 Ma (Chew \& Strachan 2014). Hence, the timing of the growth and obduction of the Ballantrae Complex has an important bearing on the Caledonian geology of Scotland and beyond.

The ophiolitic Ballantrae Complex comprises two belts of serpentinised ultramafic rock (the Northern and Southern Serpentinite Belts) extending NE-SW and separating three belts of mostly lavas and volcanic breccias that together comprise the Balcreuchan Group (Fig. 1). From the Balcreuchan Group succession there is abundant evidence of polygenetic volcanism, with an abundance of geochemical evidence indicating eruption in a variety of island arc, within-plate and spreading ridge geotectonic settings. Most of the complex's major internal boundaries are formed by steeply inclined, post-obduction faults but an important exception is the dynamothermal metamorphic aureole preserved along part of the southern margin of the Northern Serpentinite Belt and thought to have been formed during the tectonic juxtaposition of its mantle protolith with the now-adjacent crustal volcanic rocks of the Balcreuchan Group (Spray \& Williams 1980; Treloar et al. 1980). The age of the metamorphism that created the aureole was reported by Bluck et al. (1980) to be 478 $\pm 8 \mathrm{Ma}(\mathrm{K}-\mathrm{Ar}$, hornblende in amphibolite) and this has been recently confirmed by 
Stewart et al. (2017) who reported an age of 477.6 $\pm 1.9 \mathrm{Ma}(\mathrm{Sm}-\mathrm{Nd}$, garnet in amphibolite/granulite).

The radiometric age control on the volcanic and plutonic components of the Complex is based mostly on $\mathrm{K}-\mathrm{Ar}$ or $\mathrm{Sm}-\mathrm{Nd}$ analyses. The ages obtained, some with relatively large errors and mostly published in the early 1980s (summarised in Stone 2014, fig. 7 therein), establish a broad Late Cambrian to Middle Ordovician range. The most precise is the $483 \pm 4 \mathrm{Ma}(\mathrm{U}-\mathrm{Pb})$ reported by Bluck et al. (1980) from zircon in a leucotonalite intruded into and chilled against ultramafic rock of the Northern Serpentinite Belt. Several graptolite faunas have been recovered from sedimentary interbeds within the within-plate volcanogenic successions (Peach \& Horne 1899; Dewey et al. 1970; Stone \& Rushton 1983; Rushton et al. 1986) and these establish an Early Arenig (Floian) age in the range 470 to 478 Ma. Throughout this paper, correlation of the British Ordovician Series with Global Stages follows Bergström et al. 2008. The time scale correlations follow Cooper \& Sadler (2012), which is a robust global standard scaled against chronometric dates.

Whilst there is reliable evidence for the age of the ophiolitic components of the Ballantrae Complex, the timing of its final obduction is not so well defined. An absolute termination of that process must have preceded deposition of the Llanvirn age beds at the base of the unconformably overlying sedimentary succession, the Barr Group, which contains, a little above its base, an Early Llanvirn (mid-Abereiddian) conodont fauna (Bergström 1983). This would indicate an age for the oldest Barr Group strata of about $463 \mathrm{Ma}$ (Cooper \& Sadler 2012). However, to the NE of the main Ballantrae Complex outcrop, a small inlier at Craighead contains basaltic lavas that appear to be associated with chert containing conodonts that are most probably no older than uppermost Arenig (about 466 Ma) in age (Ingham 1978; Bergström 1990). If the Craighead lavas and cherts are assigned to the Ballantrae Complex, only a relatively short time interval remains between their accumulation and their structural incorporation into the obducted ophiolite. This problem has been recently accentuated by the $\mathrm{U}-\mathrm{Pb}$ ages of detrital zircon in volcaniclastic sandstone and tuff that suggest that unambiguous parts of the Balcreuchan Group may also extend upwards to younger ages than previously supposed, perhaps to about $464 \mathrm{Ma}$ (Fujisaki et al. 2015). 
Hence, an unresolved problem in interpretations of the Ballantrae Complex is the short length of time apparently intervening between eruption and intrusion of igneous lithologies integral to it, and its subsequent burial beneath a sedimentary cover. Between these two processes the tectonic assembly of the complex and its final obduction had been completed, followed by its uplift, erosion and downthrow by extensional faulting. The overall age-range for generation and obduction of the Complex is not the issue, with similar sequences of events described from some of the Irish ophiolites (e.g. Hollis et al. 2012 and references therein). Rather, the interpretational difficulties at Ballantrae arise from evidence that oceanic generation of parts of the Complex continued beyond the time at which obduction might have been expected to be complete. This paper reviews the evidence relevant to the age paradox and highlights the outstanding difficulties. Given the associations that have been made between obduction of the Ballantrae Complex and initiation of the Grampian Orogeny, these questions have a significant bearing on other aspects of Scottish Caledonian geology.

\section{The age of the basal Barr Group unconformity}

A decisive upper age limit to the development of the Ballantrae Complex is provided at the northern and eastern margins of its outcrop by the unconformable base of the overlying Barr Group (Fig. 2). The Barr Group ranges from the Early Llanvirn up into the Caradoc and its basal division, the Kirkland Conglomerate Formation (up to 245 m thick), overlies lavas of the Balcreuchan Group unconformably (e.g. Floyd 1999, p. 32); most of the contained clasts are of lithologies that could have been derived from the Ballantrae Complex (Ince 1984). The overlying Auchensoul Limestone and Confinis Flags formations (up to $18 \mathrm{~m}$ and about $95 \mathrm{~m}$ thick respectively) yield shallow-water shelly faunas that can be correlated with the upper Whiterockian of eastern North America (c. 463-457 Ma) (Ingham 2000). A more precise age is provided by conodonts in the succeeding Stinchar Limestone Formation (up to $67 \mathrm{~m}$ thick): these include representatives of the Pygodus serra biozone and, at a higher level, the Pygodus anserinus biozone (Bergström 1971). The serra-anserinus biozonal boundary, present within the Stinchar Limestone, is an important level and is widely recognised (Bergström 1983, p. 44; Bergström et al. 2000). According to 
Cooper \& Sadler (2012, fig. 20.1 therein) the serra biozone extends from the midDarriwilian (upper part of Da3) to the lower part of Da4, representing an age of about 462.5 Ma to 460.5 Ma; the anserinus biozone extends through most of the Da4 interval to above the base of the Sandbian epoch, from 460.5 Ma to about $458 \mathrm{Ma}$.

The Barr Group probably started to accumulate as a transgressive cover-sequence at about, or a little before, $462 \mathrm{Ma}$ (Fig. 2). A eustatic sea-level rise, the Furudal Highstand, is postulated at just about this time (Late Darriwilian: Nielsen 2004, p. 88), but it has long been recognised that local tectonics were the principal control on the fault-controlled transgression across the Ballantrae Complex (Williams 1962; Ince 1984 and references therein). There is evidence of tectonic instability and significant fault-control of sedimentation, with major changes in thickness of the Ordovician conglomerate units across contemporaneous, broadly east-west faults. The faults developed sequentially northwards, with downthrow to the south, and so produced a northward transgressive onlap by the sedimentary succession.

\section{The timing of obduction}

An early stage in the obduction of the Ballantrae Complex, or at least a fundamental stage in its tectonic development, is dated to about $478 \mathrm{Ma}$ by geochronology results from the dynamothermal metamorphic aureole adjacent to the south-east margin of the Northern Serpentinite Belt (Table 1): $478 \pm 8 \mathrm{Ma}(\mathrm{K}-\mathrm{Ar}$ ) from hornblende in amphibolite (Bluck et al. 1980) and 477.6 $\pm 1.9 \mathrm{Ma}(\mathrm{Sm}-\mathrm{Nd})$ from garnet in amphibolite/granulite (Stewart et al. 2017). The aureole was created when ultramafic rock was thrust over a volcanic succession that forms part of the Tremadoc - Arenig Balcreuchan Group, but unfortunately there is no independent evidence for the age of that particular volcanic succession.

At a late stage in the obduction process, and as a by-product of serpentinisation, some of the ultramafic rock was converted to 'ophicarbonate', a secondary assemblage of carbonate (mostly dolomite) and quartz associated with polyphase carbonate-quartz veining. Relic chrome spinel grains are a clear indication of the ultramafic origin, and clasts of ophicarbonate with spinel grains are present in the conglomerate and mélange/olistostrome deposits interbedded with graptolitic mudstone of early Arenig 
age (c. 477-471 Ma) (Bailey \& McCallien 1957). By that time altered and serpentinised ultramafic rock was available for erosion.

The youngest of the Arenig graptolite faunas recovered from the Balcreuchan Group is that recovered from a mineral exploration borehole at North Ballaird (Stone \& Strachan 1981). For reasons of Ordovician palaeogeography, this fauna, and all of the others from the Balcreuchan Group, are most readily assigned to biozones defined in Australia, and are related to the British Series using the correlations of Bergström et al. 2008. The North Ballaird fauna may possibly be of early Yapeenian (Ya1) age (Stone \& Rushton 2003) but is probably more reliably assigned to the preceding late Castlemainian (Ca4) (Maletz 2004) as shown in Fig. 3. This graptolite fauna is the best preserved and most prolific that has been recovered from anywhere in the Ballantrae Complex and the short time-ranges of the graptolite biozones at this stratigraphical level must be stressed. The borehole proved a succession in which thinly interbedded chert, tuff, microconglomerate and graptolitic mudstone overlay polymict breccia that in turn overlay a breccia of angular, silicified serpentinite clasts. It is particularly noteworthy that a microconglomerate immediately overlying the graptolitic mudstone contains 'ophicarbonate' clasts that are encrusted by algal laminae (Stone \& Smellie 1988, fig. 32 therein). Clearly these clasts of altered ultramafic rock originated at or a little before $468.5 \mathrm{Ma}$ (Fig. 3), in a shallow-water environment. From these relationships, Stone \& Rushton (2003) argued that the North Ballaird succession represented syn-obduction deposition.

\section{The Craighead Inlier}

“[T]here may be little, if any, time gap between the youngest Ballantrae rocks at Craighead and the lowest part of the Stinchar Valley [Barr Group] succession" (Ingham 1978, p. 167).

The Craighead Inlier, about 7 km north-east of Girvan (Fig. 1), has an uncertain and potentially anomalous relationship with the Ballantrae Complex. The oldest rocks within the inlier are basaltic pillow lavas and associated chert. The lavas are commonly assumed to form the northern exposed extremity of the Tremadoc - Arenig Ballantrae Complex. The chert might have been coeval with the pillow lavas but was 
also interpreted as a younger unconformable cover subsequently infolded with them, because conodonts obtained by Lamont \& Lindström (1957, p. 65) suggest, in current terms, the Pygodus anserinus and/or P. serra conodont biozones (Bergström 1971) of Late Llanvirn to earliest Caradoc age. Although Ingham (1978, p. 167) thought the conodonts were most likely to indicate a level low in the $P$. serra biozone (Fig. 2), that is with an age of about 462 Ma, Bergström (1990, p. 5) disagreed. In that comprehensive review of Upper Ordovician conodonts from the Girvan succession, Bergström considered the age of the Craighead conodonts to be "far less conclusive" than had earlier been supposed, and that they "could represent a horizon anywhere in the Llanvirn or Llandeilo, if not in the uppermost Arenig or lowermost Caradoc", a potential age range of about $466 \mathrm{Ma}-458 \mathrm{Ma}$ (Fig. 2, but note that the Llandeilian is now taken as the upper stage of the Llanvirn).

Despite the possibility that the Craighead chert might be as old as uppermost Arenig (early Darriwilian), it would still seem to be younger than the likely mid-Arenig (late Floian) minimum age established for the Ballantrae Complex lavas (as discussed in detail below). One solution to the Craighead problem therefore remains the assumption that the lavas are coeval with those of the Ballantrae Complex and have been tectonically intercalated with younger chert. But depending on the exact relationship of the cherts with the lavas, it remains possible that the latter are younger than those of the Ballantrae Complex sensu stricto. In that case, as suggested by Stone (2014, p. 11) the Craighead lavas could be post-obduction eruptives, perhaps linked to some of the demonstrably post-obduction (but pre-Barr Group) intrusions seen within the main outcrop of the Ballantrae Complex.

\section{The age of the Balcreuchan Group}

A broadly Late Cambrian to Middle Ordovician age for the Balcreuchan Group is loosely constrained by several radiometric dates with relatively large errors (Bluck et al. 1980; Thirlwall \& Bluck 1984; Sawaki et al. 2010), which have been summarised by Stone (2014, fig. 7 therein). More precise ages for some of the within-plate volcanic components of the group are provided by graptolite faunas recovered from sedimentary interbeds at Pinbain (Rushton et al. 1986) and at several localities in the vicinity of Bennane Head (Stone \& Rushton 1983). These all lie within the Early 
Arenig (Floian), spanning the Lancefieldian 3 to Chewtonian 2 biozones (Fig. 3). The Bendigonian age from Pinbain dates the base of that volcanogenic succession. The ages from Bennane Head range higher both biostratigraphically and in the local lithostratigraphy and are particularly relevant to the discussion pursued in this paper.

\section{The Bennane Head to Bennane Lea succession}

From Balcreuchan Port, southwards across Bennane Head to Bennane Lea (Fig. 1), a within-plate volcanogenic succession, about $700 \mathrm{~m}$ thick, is steeply inclined and youngs consistently to the south (Stone \& Smellie 1988, see especially Table 5 therein). Aphyric and feldsparphyric lavas form the lower half of the succession but the distribution of graptolite faunas within it proves three structural repetitions (Stone \& Rushton 1983). In the southernmost of these, the lavas pass up, apparently conformably, through breccias and more aphyric lavas into a thin sedimentary cover of interbedded conglomerate, sandstone, tuff and chert that is now well exposed on the coast at Bennane Lea. Bluck (1992) noted the similarity of the overall succession to layers 1 and 2 of normal oceanic crust, but also emphasised discrepancies: the presence of glass shards and accretionary lapilli (more indicative of arc volcanism) in the chert at Bennane Lea, and the abundant evidence there, from the conglomerate and chert, for slumping and soft-sediment deformation.

The Bennane Lea section was described by Peach \& Horne (1899, p. 434, figure 103, plates 7-9) as one where "radiolarian cherts, Middle Arenig graptolite shales, and underlying volcanic rocks are thrown into a series of sharp folds" (Fig. 4). After a detailed study of the section, Bluck $(1978,1992)$ described extensional and compressional soft-sediment deformation structures affecting the chert-tuff interbeds, with slump-driven intermingling of the chert and conglomerate. Planes of discontinuity which cut out parts of the chert sequence were interpreted as slide planes developed in the unconsolidated sediments. More recently, Sawaki et al. (2010) and Fujisaki et al. (2015) have reinterpreted the Bennane Lea section in tectonic terms as the uppermost part of an 'ocean-plate stratigraphy' that has been structurally imbricated by layer-parallel thrust into a series of duplexes, each containing parts of essentially the same lithostratigraphy: pillow basalt succeeded by chert (with tuff interbeds) succeeded by sandstone/breccia/conglomerate. This 
structural reinterpretation, referred to an accretionary prism, is difficult to reconcile with the folding of the section and begs many questions that are beyond the scope of this paper.

Structural issues aside, of more direct relevance to the present discussion are the dating results presented by Fujisaki et al. (2015) from zircons contained in the sandstones and tuff interbeds. Prior to the availability of the zircon dates, age control on the Bennane Lea succession was provided by a graptolite fauna from mudstone associated with lava and volcanic breccia immediately beneath the chert succession. The graptolite fauna from this locality was first recorded by Lapworth (1889, p. 20) and expanded by Macconochie as reported by Peach \& Horne (1899, p. 435). Based on these discoveries, supplemented by new collections, Stone \& Rushton (1983) assigned the fauna to a position within the Bendigonian 3 to Chewtonian 2 biozones. We have reviewed the fauna, also taking into account the notes by Dewey et al. (1970, pp. 39-40) on the Lapworth and Macconochie collections; all are reassessed in the light of the biostratigraphical review of Ordovician graptolites in Australasia (VandenBerg and Cooper (1992). The more age-diagnostic species from Bennane Lea include the following (their ranges are given using the abbreviations in Fig. 3): Sigmagraptus praecursor (Be1 - Ch2), Phyllograptus anna (Be2-Ca1), Didymograptellus cf. protomurchisoni (from the D. bifidus Zone of North America, = Chewtonian), Tetragraptus cf. kindlei [of Bouček] (from the Czech equivalent of the Chewtonian), the 3-stiped form of Tetragraptus fruticosus from Bennane Head [as figured by Elles \& Wood, 1902, pl. 6, figs 2a, b], now formally named Tshallograptus tridens VandenBerg, 2017 (Be3 - Ch1). This association indicates the Chewtonian

Stage, with a relatively weak indication of the lower biozone, Ch1 (472.5 Ma to 471.5 Ma (Fig. 3).

\section{Detrital zircons in sandstone at Bennane Lea}

The distribution of $\mathrm{U}-\mathrm{Pb}$ ages for the zircon populations in two sandstone interbeds were illustrated by Fujisaki et al. (2015, fig. 10 therein); the zircons were thought to be derived from island arc volcanicity. Pronounced maxima in the frequency distribution of the ages obtained were at c. $467 \mathrm{Ma}$ in one example and at c. $478 \mathrm{Ma}$ in the other. These results, when compared with the Chewtonian age of the graptolite 
fauna in the underlying mudstone (472.5 Ma to $470.5 \mathrm{Ma}$ - or possibly to only 471.5 $\mathrm{Ma}$ if $\mathrm{Ch} 1$ is correct), suggest that arc volcanicity in the sandstone provenance area both preceded and followed deposition of the mudstone and eruption of its associated within-plate basalts. The depositional circumstances, whereby sandstone derived from a volcanic arc was transported into an area in which within-plate lavas were erupted can be matched with the situation at the base of the Pinbain succession in the north of the Ballantrae Complex. There, Smellie \& Stone (2001) described sandstone with the geochemical characteristics of island-arc volcanism overlain by basalt lavas with within-plate geochemistry. A graptolite fauna from the sandstone succession is of Bendigonian age (Rushton et al. 1986), equivalent to a range of $476 \mathrm{Ma}$ to $472.5 \mathrm{Ma}$. These equivalent relationships may serve to strengthen the broad correlation of the Pinbain and Bennane successions as lateral equivalents, a correlation that was extended to the Balcreuchan Group succession at Knockdolian (Fig.1) by Stone (2014) on lithostratigraphical grounds.

\section{Volcanogenic zircons in tuff at Bennane Lea}

The first U-Pb zircon date from tuff in the Bennane Lea chert succession, $470 \pm 10$ Ma, was provided by Sawaki et al. (2010). This relatively imprecise date was well within error of both the graptolite biostratigraphy and the Arenig age confirmed by the chert's radiolarian fauna (Aitchison 1998). More detailed follow-up work then produced a series of much more closely constrained dates that were linked by Fujisaki et al. (2015) to three tuff horizons within the chert succession (Fig. 3). The dates obtained range from the late Tremadoc to the early Llanvirn but are complicated by apparent inversions whereby in some of the sampled sections the oldest tuff bed 'overlies' the youngest. This reversal was ascribed either to soft sediment deformation prior to or during thrust imbrication, or to subsidiary thrust relationships within each of the defined duplexes. The tight folding seen at Bennane Lea may also be a factor but was not invoked as a potential explanation by Fujisaki et al. (2015). Irrespective of the details, and whether syn-sedimentary or tectonic disruption is preferred, the range of dates has wider implications at both its older and younger ends. Fujisaki et al. (2015, p. 326) summarised their results as follows: 
"The units of OPS [ocean plate stratigraphy] exposed at Bennane Lea formed in a pelagic environment from ca. $477 \mathrm{Ma}$ to $464 \mathrm{Ma}$. Later, these OPS packages were accreted into a forearc in the subduction-accretion complex."

Fujisaki et al. (2015, fig. 6 therein) consolidated their data into three episodes of volcanicity and tuff deposition at about $477 \mathrm{Ma}, 470 \mathrm{Ma}$ and $464 \mathrm{Ma}$. Even allowing for the uncertainty introduced by the error ranges the age of the oldest tuff bed, c. 477 $\mathrm{Ma}$, is at odds with the Chewtonian age of the graptolite fauna in the supposedly underlying succession of lava and mudstone (Fig. 3). This contradiction could be resolved in two ways. Firstly, the zircons may not have been erupted contemporaneously with deposition but were instead derived from an older provenance, as with the volcaniclastic sandstone showing a detrital zircon population peak at $478 \mathrm{Ma}$ (Fujisaki et al. 2015, fig. 10 therein); the small age range of the analysed zircons perhaps militates against this solution. Secondly, the chert/tuff succession could be faulted against the lava/breccia/graptolitic mudstone succession instead of conformably overlying it, albeit this solution would fundamentally weaken the overall interpretation of the Bennane Lea section as typical OPS. However this complication is resolved, of more importance for the issues discussed in the present paper are the younger zircon dates from Bennane Lea.

The c. $470 \mathrm{Ma}$ age of the middle of the three tuff layers identified by Fujisaki et al. (2015) is compatible with all of the available biostratigraphic data, but the youngest of the three tuffs, placed by Fujisaki et al. at approximately $464 \mathrm{Ma}$, reintroduces the problem of proximity to the $463 \mathrm{Ma}$ age of the base of the unconformably overlying Barr Group sedimentary rocks. In their interpretation, Fujisaki et al. consider the tuffs to have been erupted at an intra-oceanic arc until at least $464 \mathrm{Ma}$, with the neighbouring, pelagic chert/tuff, 'ocean plate stratigraphy' then carried southwards into a south-directed subduction zone beneath that arc (the imbrication geometry of the Bennane Lea succession was taken as evidence for southward subduction although the folding of the succession would surely complicate that interpretation). Thereafter, arc-continent collision and subduction reversal led to obduction and structural assembly of the Ballantrae Complex at the margin of Laurentia, which was followed by the uplift and erosion of the Complex, then its transgression by an unconformably overlying sedimentary succession (the Barr Group) from about 463 Ma onwards. 
In reality, the timing dilemma may not be as great as the interpretation of Fujisaki et al. (2015) would imply, because the error ranges given in their figure 8 , and illustrated here in Fig. 3, allow the youngest tuff bed to be to be as old as $468 \mathrm{Ma}$ in age. Nevertheless, it is no older than (and very probably younger than) the Castlemainian 4 (c. $468.5 \mathrm{Ma}$ ) age from the North Ballaird succession (Fig. 3), which has features suggestive of syn-obduction deposition (Stone \& Rushton 2003). Hence, the problem remains: parts of the Ballantrae Complex were apparently still being generated in an oceanic setting whilst other parts were being tectonically juxtaposed.

Fujisaki et al. (2015) suggested that the source of the zircon crystals and tuff beds in the Bennane Lea succession was an intra-oceanic volcanic arc that was itself ultimately incorporated into the Ballantrae Complex, but it is worth noting a possible alternative. About $140 \mathrm{~km}$ south west from Ballantrae, in the Irish extension of the Midland Valley Terrane, the Tyrone Igneous Complex contains magmatic arc intrusions generated by continent-directed subduction of Iapetus Ocean crust and dated to about 470-464 Ma (Cooper et al. 2011). These Irish dates are a good match for the younger range of Bennane Lea zircon ages, but data from Scotland, although less precise, are not far removed. Granitoid boulders in the Benan Conglomerate Formation, the upper part of the Barr Group (Fig. 2), are derived from the north and have yielded $\mathrm{Rb}-\mathrm{Sr}$ ages in the range $459 \pm 10 \mathrm{Ma}$ to $471 \pm 13 \mathrm{Ma}$ (Longman et al. 1979); U-Pb ages of detrital zircons in Silurian sandstones of the Midland Valley show a distribution peak at about $475 \mathrm{Ma}$ (Phillips et al. 2009). All of this dated igneous material is believed to have been eroded from a Midland Valley magmatic arc. Derivation of the Bennane Lea tuffs from such a source would obviate the need for late, intra-oceanic subduction and arc volcanism at Ballantrae.

\section{Evidence for the polyphase assembly of the Ballantrae Complex}

"From a consideration of the structure of the ophiolite and the type of debris in the conglomerates, it is probable that the ophiolite was compound or at least structurally complex at the time of its obduction." (Bluck 1978, p.161). 
One way in which some of the timing issues within the Ballantrae Complex might be addressed was examined by Bluck (2001) who proposed four sequential episodes of 'obduction' in which various components were tectonically juxtaposed and elevated, with intervening episodes of oceanic volcanism the products of which were caught-up in the succeeding obduction event(s). Part of Bluck's evidence derived from the presence within conglomerate and mélange/olistostrome units, interbedded with the volcanogenic successions, of a range of clasts derived from all the other parts of the ophiolitic assemblage. These examples, at Pinbain, Bennane Lea, North and South Ballaird, and several other localities within the Ballantrae Complex, had been previously cited by Bluck (1978) as demonstrating erosion of an exposed ophiolite assemblage concurrent with the eruption of the youngest Balcreuchan Group volcanic rocks that were themselves subsequently incorporated into the complex.

At Pinbain, the wide range of clast types in the olistostrome unit includes amphibolite and glaucophane schist, lithologies originating at considerable depth (Bailey \& McCallien 1957, Church \& Gayer 1973; Bluck 1978). Unfortunately, there is no reliable biostratigraphic control on the age of this deposit. As discussed previously, good examples of polymict, mass-flow conglomerates/olistostromes are also seen a few kilometres inland to the north-east of Bennane Lea, around the farms of North and South Ballaird. From the latter locality, a range of mafic and altered ultramafic lithologies were reported by Balsillie $(1937$, p. 32) in what he termed agglomerate and volcanic ash interbedded with chert and black mudstone. In the North Ballaird borehole, graptolitic mudstone indicative of the Late Castlemainian ( $\mathrm{Ca} 4)$ biozone (Stone \& Rushton 2003; Maletz 2004) i.e. 468.5 Ma (Fig. 2), was coeval with the erosion of the silicified serpentinite seen as clasts in the breccias and conglomerates with which it is stratigraphically associated (Stone \& Strachan 1981). At Bennane Lea, the breccias/conglomerates interbedded with and overlying the chert/tuff succession, although dominated by clasts of basalt lava, also contain clasts of silicified ultramafic rock (ophicarbonate), identified by their included grains of chrome-spinel (Bailey \& McCallien 1957, p.41). Deposition of these clasts of altered ultramafic rock followed the youngest tuff eruption dated by Fujisaki et al. (2015) at about $464 \mathrm{Ma}$. So, by the end of the Arenig, mantle-derived, ultramafic rock must have been brought to the surface, serpentinised and altered and exposed so that its eroded debris could be slumped into an oceanic depositional area otherwise 
accumulating the chert and tuff now preserved at Bennane Lea. Plate movement towards an active margin would seem the likely mechanism, culminating in the cherttuff-olistostrome succession being itself incorporated into the tectonically accumulating Ballantrae Complex.

Compounding the timing issues is the wide range of components included in the relatively small area, c. $75 \mathrm{~km}^{2}$, of the Ballantrae Complex. These need to have been brought together laterally from disparate oceanic environments and vertically from crustal depths ranging down to the mantle. Whilst marginal, back-arc basin models can be constructed that accommodate most of the oceanic environments dictated by the geochemistry of the igneous rocks, (e.g. Smellie \& Stone 2001; Kawai et al. 2008), the floor of that basin would need to have been structurally compound, or to have incorporated blocks of previously amalgamated ophiolitic lithologies. An alternative, in which the different components of the Ballantrae Complex were assembled largely by strike-slip tectonism (e.g. Stone 1984) is no easier to reconcile with the age constraints.

Interpretations of the Ballantrae Complex commonly associate its final obduction with the establishment of a north-directed subduction zone at the southern margin of the Midland Valley Terrane - the southernmost part of Laurentia - in the Late Arenig. This required a reversal of subduction direction from the southward orientation preferred in most models for generation of the oceanic arc and back-arc volcanic components of the Complex (e.g. Smellie \& Stone 2001; Stone 2014 and references therein), a process that was initiated by arc-continent collision. In their interpretation, Fujisaki et al. (2015, figure 11c) place subduction-reversal as late as $460 \mathrm{Ma}$, but this is uncomfortably late for most regional models. Independent evidence for a 'Midland Valley arc' generated above the north-directed subduction zone suggests that it was in fact well-established by $470 \mathrm{Ma}$. The evidence comes from dated igneous detritus believed to have been eroded from it and which is now contained in Upper Ordovician conglomerates and Silurian sandstones along the southern margin of the Midland Valley terrane. As previously noted, the northerly-derived Benan Conglomerate Formation, the upper part of the Barr Group (Fig. 2), contains granitoid boulders with $\mathrm{Rb}-\mathrm{Sr}$ ages in the range $459 \pm 10 \mathrm{Ma}$ to $471 \pm 13 \mathrm{Ma}$ (Longman et al. 1979), whilst 
detrital zircons in Silurian sandstones from several Lower Palaeozoic inliers show a distribution peak of U-Pb ages at about $475 \mathrm{Ma}$ (Phillips et al. 2009).

The conglomerate and sandstone data indicate a likely overlap, between about $475 \mathrm{Ma}$ and $465 \mathrm{Ma}$, in the timing of north-directed subduction beneath the southern margin of the Midland Valley Terrane and the continuing oceanic subduction required to generate the younger, volcanogenic parts of the Balcreuchan Group. It seems likely, therefore, that by the mid-Arenig more than one subduction zone was active, with elements of the Ballantrae Complex probably being generated and juxtaposed in association with both, prior to a final amalgamation. This situation would have increased the opportunities for the polyphase development of the Ballantrae Complex.

Finally, it is worth briefly considering how the likely development and obduction histories of the Ballantrae Complex compare with the situations established for other ophiolites. However, we stress that as many of the large, best-studied examples are Mesozoic or younger, any comparisons with the smaller, Early Palaeozoic ophiolite at Ballantrae must be approached with caution. Firstly, in terms of evidence for overlapping compressional and extensional processes, there is ample evidence that this is not unusual. From perhaps the best-known and most intensively studied of all ophiolites, the Semail Complex of Oman, Rioux et al. (2016) have shown that metamorphic rocks in the ophiolite's sole formed either shortly prior to or during the continuing generation of the ophiolite's igneous crust. More generally, at the initiation of an episode of obduction, as subduction of continental crust commences, Edwards et al. (2105) have shown experimentally that back-arc extension can continue whilst deformation and shortening in the forearc region increases. Secondly, in terms of the speed at which obduction can proceed, the Semail Complex again provides an instructive example. Hacker et al. (1996) note that most ophiolites are relatively young ( $<20$ m.y.) at the time of their obduction and that for the Semail ophiolite the initial stages of emplacement occurred only about 1-2 m.y. after active magmatism; thereafter obduction proceeded rapidly at approximately $25-33 \mathrm{~km} / \mathrm{m}$.y. At Ballantrae, the time available for obduction would appear to be somewhere between $1 \mathrm{~m} . \mathrm{y}$. and about 4 m.y. Although the spatial scale of obduction at Ballantrae is uncertain, such a comparison suggests that the rate of progress required by the data discussed in this 
paper is not unreasonable, albeit at the rapid end of the range and allowing minimal time for post-obduction processes.

\section{Conclusions}

Arguments in favour of the polyphase tectonic assembly of the Ballantrae Complex are not new. Bluck (1978) pointed to the included, polymict olistostromes as evidence for the erosion of the early-formed parts of the complex into successions that were themselves subsequently incorporated, and the process has been widely discussed (Stone 2014 and references therein). Graptolite biostratigraphy shows that at least some of the olistostrome emplacement took place at about 468.5 Ma (Castlemainian 4: Stone \& Rushton 2003; Maletz 2004).

The tectonic assembly of the complex - 'obduction' sensu stricto may have been only the final episode - was in progress by about $478 \mathrm{Ma}$. That is determined by the 477.6 $\pm 1.9 \mathrm{Ma}$ age (Stewart et al. 2017) of dynamothermal metamorphism at the margin of the Northern Serpentinite Belt. At about the same time, and for at least ten million years thereafter, parts of the Balcreuchan Group were being erupted in a within-plate oceanic setting prior to their incorporation into the complex. Graptolite biostratigraphy places that volcanism within the 478-471 Ma range (Stone \& Rushton 1983) (Fig. 3), whilst radiometric dating of zircon from tuff interbeds in a chert succession that may overlie within-plate volcanic rocks, appears to show oceanic sedimentation continuing to at least $468 \mathrm{Ma}$ and possibly to about $464 \mathrm{Ma}$ (Fujisaki et al. 2015). It was followed by olistostrome emplacement as, or just before, the chert succession approached and was tectonically incorporated into the burgeoning Ballantrae Complex. This timing must be set against the requirement for the whole of the Ballantrae Complex to be in place, uplifted and eroded, and then downfaulted, by $463 \mathrm{Ma}$, the basal age, from conodont and brachiopod biostratigraphy, of the Barr Group strata that unconformably overlies the ophiolitic rocks.

The situation in the Craighead Inlier remains uncertain and may compound the difficulties. If the Craighead lavas are accepted as part of the Ballantrae Complex, if they prove to be coeval with the closely associated chert, and if the age of the chert lies within the younger part of the likely range, then the difficulty of accommodating 
all the necessary processes into a very short time span - as noted by Ingham (1978) becomes even more acute.

Of course, there are uncertainties in all the age data presented and particularly in the correlation of biostratigraphy with a dated time-scale. Nevertheless, acceptance of a protracted and polyphase history for the Ballantrae Complex, but with a rapid final stage of emplacement, seems unavoidable. The overall age range for the tectonic assembly and ultimate obduction of the Complex is about 478-464 Ma. The process has been linked to the initiation of the Grampian Orogeny in Scotland (e.g. Bluck et al. 1980; Oliver et al. 2000; Stewart et al. 2017) for which a relatively short time span has been proposed: e.g. 480-465 Ma (Oliver 2001) or 475-465 Ma (Chew \& Strachan 2014). Although there is a close correspondence between the apparent timing of the two processes there need not be a causal link. The driving force for the Grampian Orogeny was most probably the collision of the Midland Valley Terrane with the margin of the Laurentian continent (e.g. Tanner 2014, see especially figure 17 therein) resulting in the elimination of a Dalradian Basin and obduction of the Highland Border ophiolite. Contemporaneous events on the Iapetus Ocean side of the Midland Valley Terrane, culminating in the obduction of the Ballantrae Complex, may have no direct relationship with the progress of the Grampian Orogeny further north. This possibility is strengthened if, as seems likely, the principal obduction tectonics at Ballantrae took place relatively late in the overall structural assembly of the Complex, and so coincided with only the later stages of the Grampian Orogeny.

\section{Acknowledgements}

The late Professor Brian Bluck (University of Glasgow) made important contributions to our understanding of the Ballantrae Complex and his influence on the ideas explored in this paper is readily acknowledged. The paper has benefitted from reviews by Alan Owen (University of Glasgow) and three anonymous referees whose comments have been helpful, challenging and provocative. The paper is published by permission of the Executive Director, British Geological Survey. We thank Craig Woodward (BGS, Edinburgh) for assistance in the preparation of the figures.

\section{References}


Aitchison, J.C. 1998. A Lower Ordovician (Arenig) radiolarian fauna from the Ballantrae Complex, Scotland. Scottish Journal of Geology. 34, 73-81.

Bailey, E.B. \& McCallien, W.J. 1957. The Ballantrae Serpentine, Ayrshire. Transactions of the Edinburgh Geological Society, 17, 33-53.

Balsillie, D. 1937. Further observations on the Ballantrae Igneous Complex, South Ayrshire. Geological Magazine, 74, 20-33.

Bergström, S.M. 1971. Conodont biostratigraphy of the Middle and Upper Ordovician of Europe and eastern North America. Geological Society of America, Memoir, 127, 83-161.

Bergström, S.M. 1983. Biogeography, evolutionary relationships and biostratigraphic significance of Ordovician platform conodonts. Fossils and Strata, 15, 35-58.

Bergström, S.M. 1990. Biostratigraphic and biogeographic significance of Middle and Upper Ordovician conodonts in the Girvan succession, south-west Scotland. Courier Forschungsinstitut Senckenberg, 118, 1-43.

Bergström, S.M., Finney, S.C., Chen Xu, Pålsson, C., Wang Zhi-hao \& Grahn, Y. 2000. A proposed global boundary stratotype for the base of the Upper Series of the Ordovician System: The Fågelsång section, Scania, southern Sweden. Episodes, 23, 102-109.

Bergström, S.M., Xu Chen, Gutiérrez-Marco, J.C. \& Dronov, A. 2008. The new chronostratigraphic classification of the Ordovician System and its relations to major regional series and stages and to $\delta^{13} \mathrm{C}$ chemostratigraphy. Lethaia, 42, 97-107.

Bluck, B.J. 1978. Geology of a continental margin 1: the Ballantrae Complex. In: Bowes, D.R \& Leake, B.E. (eds) Crustal evolution in northwestern Britain and adjacent regions. Geological Journal Special Issue, 10, 151-162.

Bluck, B.J. 1992. Bennane Head to Downan Point. In: Lawson, J.D. \& Weedon, D.S. (eds) Geological Excursions around Glasgow and Girvan. Geological Society of Glasgow. 347-361.

Bluck, B.J. 2001. Caledonian and related events in Scotland. Transactions of the Royal Society of Edinburgh: Earth Sciences, 91, 375-404.

Bluck, B.J., Halliday, A.N., Aftalion, M. and Macintyre, R.M. 1980. Age and origin of Ballantrae ophiolite and its significance to the Caledonian orogeny and Ordovician time scale. Geology, 8, 492-495.

Chew, D.M. \& Strachan, R.A. 2014. The Laurentian Caledonides of Scotland and Ireland. In: Corfu, F., Gasser, D. \& Chew, D.M. (eds). New Perspectives on the Caledonides of Scandinavia and Related Areas. Geological Society, London, Special Publication. 390, 45-91. 
Church, W.R. \& Gayer, R.A. 1973. The Ballantrae Ophiolite. Geological Magazine, 110, 497-510.

Cooper, M.R., Crowley, Q.G., Hollis, S.P., Noble, S.R., Roberts, S., Chew, D., Earls, G., Herrington, R. \& Merriman, R.J. 2011. Age constraints and geochemistry of the Ordovician Tyrone Igneous Complex, Northern Ireland: implications for the Grampian orogeny. Journal of the Geological Society, London, 168, 837-850.

Cooper, R.A. \& Sadler, P.M. 2012. The Ordovician Period. In: Gradstein, F.M., Ogg, J.G., Schmitz, M.D. \& Ogg, G.M. (eds). The Geologic Time Scale 2012. Elsevier, Oxford, Amsterdam \& Waltham MA. 489-523.

Dewey, J. F., Rickards, R. B. \& Skevington, D. 1970. New light on the age of Dalradian deformation and metamorphism in western Ireland. Norsk Geologisk Tidsskrift, 50, 19-44.

Edwards, S.J., Schellart, W.P. \& Duarte, J.C. 2015. Geodynamic models of continental subduction and obduction of overriding plate forearc oceanic lithosphere on top of continental crust. Tectonics, 34, 1494-1515.

Elles, G. L., \& Wood, E. M. R. 1902. A monograph of British Graptolites, Part 2, ixxviii, 55-102, pls. 5-13. Monograph of the Palaeontographical Society, London.

Floyd, J.D. 1999. Geology of the Carrick - Loch Doon district. Memoir of the British Geological Survey, Sheets 8W and 8E (Scotland).

Fujisaki, W., Asanuma, H., Suzuki, K., Sawaki, Y., Sakata, S., Hirata, T., Maruyama, S. \& Windley, B.F. 2015. Ordovician ocean plate stratigraphy and thrust duplexes of the Ballantrae Complex, SW Scotland: Implications for the pelagic deposition rate and forearc accretion in the closing Iapetus Ocean. Tectonophysics, 662, 312-327. http://dx.doi.org/10.1016/j.tecto.2015.04.014

Hacker, B.R., Mosenfelder, J.L. \& Gnos, E. 1996. Rapid emplacement of the Oman ophiolite: Thermal and geochronological constraints. Tectonics, 15, 1230-1247.

Hollis, S.P., Roberts, S., Cooper, M.R., Earls, G., Herrington, R., Condon, D.J., Cooper, M.J., Archibald, S.M. \& Piercey, S.J. 2012. Episodic arc-ophiolite emplacement and the growth of continental margins: Late accretion in the Northern Irish sector of the Grampian-Taconic orogeny. Geological Society of America Bulletin, 124, 1702-1723.

Ince, D. 1984. Sedimentation and tectonism in the Middle Ordovician of the Girvan district, SW Scotland. Transactions of the Royal Society of Edinburgh: Earth Sciences, 75, 225-237.

Ingham, J.K. 1978. Geology of a continental margin 2: middle and late Ordovician transgression, Girvan. In: Bowes, D.R \& Leake, B.E. (eds) Crustal evolution in northwestern Britain and adjacent regions. Geological Journal Special Issue, 10, $163-176$. 
Ingham, J.K. 2000. Scotland: the Midland Valley Terrane - Girvan. In: Fortey, R.A., Harper, D.A.T., Owen, A.W., Parkes, M.A., Rushton, A.W.A. \& Woodcock, N.H. A revised correlation of Ordovician rocks in the British Isles. Geological Society, London, Special Report 24, 43-47.

Kawai, T., Windley, B.F., Shibuya, T., Omori, S., Sawaki, Y. \& Maruyama, S. 2008. Large P-T gap between Ballantrae blueschist/garnet pyroxenite and surrounding ophiolite, southern Scotland, UK: Diapiric exhumation of a Caledonian serpentinite mélange. Lithos, 104, 337-354.

Lamont, A. \& Lindström, M. 1957. Arenigian and Llandeilian Cherts identified in the Southern Uplands of Scotland by means of Conodonts, etc. Transactions of the Edinburgh Geological Society, 17, 60-71.

Lapworth, C. 1889. On the Ballantrae rocks of South Scotland and their place in the Upland sequence. Geological Magazine, 6, 20-24 \& 59-69.

Longman, C.D., Bluck, B.J. \& van Breeman, O. 1979. Ordovician conglomerates and the evolution of the Midland Valley. Nature, London, 280, 578-581.

Maletz, J. 2004. Late Castlemainian (Ca 4, Arenig) graptolites from the Ballantrae Complex, SW Scotland: discussion, with reply by Stone, P. and Rushton, A.W.A. Scottish Journal of Geology, 40, 185-187.

Nielsen, A.T. 2004. Ordovician sea level changes: a Baltoscandian perspective. In: Webby, B. D., Paris, F., Droser, M. L. \& Percival, I. G. (eds). The great Ordovician biodiversification event. Columbia University Press, New York, 84-93.

Oliver, G.J.H. 2001. Reconstruction of the Grampian episode in Scotland: its place in the Caledonian Orogeny. Tectonophysics, 332, 23-49.

Oliver, G.J.H., Chen, F., Buchwaldt, R. \& Hegner, E. 2000. Fast tectonometamorphism and exhumation in the type area of the Barrovian and Buchan zones. Geology, 28, 459-462.

Peach, B.N. \& Horne, J. 1899. The Silurian Rocks of Britain. Vol 1. Scotland. Memoirs of the Geological Survey of the United Kingdom. HMSO.

Phillips, E.R., Smith, R.A., Stone, P., Pashley, V. \& Horstwood, M. 2009. Zircon age constraints on the provenance of Llandovery to Wenlock sandstones from the Midland Valey terrane of the Scottish Caledonides. Scottish Journal of Geology, 45, $131-146$.

Rioux, M., Garber, J., Bauer, A., Bowring, S., Searle, M. Kelemen, P. \& Hacker, B. 2016. Synchronous formation of the metamorphic sole and igneous crust of the Semail ophiolite: New constraints on the tectonic evolution during ophiolite formation from high-precision U-Pb zircon geochronology. Earth and Planetary Science Letters, 451, 185-195. 
Rushton, A.W.A., Stone, P., Smellie, J.L. \& Tunnicliff, J.P. 1986. An early Arenig age for the Pinbain sequence of the Ballantrae Complex. Scottish Journal of Geology, 22, 41-54.

Sawaki, Y., Shibuya, T., Kawai, T., Komiya, T., Omori, S., Iizuka, T., Hirata, T., Windley, B.F. \& Maruyama, S. 2010. Imbricated ocean-plate stratigraphy and U-Pb zircon ages from tuff beds in cherts in the Ballantrae complex, SW Scotland. Geological Society of America Bulletin, 122, 454-464.

Smellie, J.L. \& Stone, P. 2001. Geochemical characteristics and geotectonic setting of early Ordovician basalt lavas in the Ballantrae Complex ophiolite, SW Scotland. Transactions of the Royal Society of Edinburgh: Earth Sciences, 91 (for 2000), 539555.

Spray, J.G. \& Williams, G.D. 1980. The sub-ophiolite metamorphic rocks of the Ballantrae Igneous Complex, SW Scotland. Journal of the Geological Society, London, 137, 359-368.

Stewart, E.M., Baxter, E.F. \& Ague, J.J. 2017. Initiation and duration of Grampian orogenesis constrained by refined Sm-Nd garnet geochronology of the Ballantrae ophiolite, Scotland. Journal of the Geological Society, London, 174, 968-978.

Stone, P. 1984. Constraints on genetic models for the Ballantrae Complex, SW Scotland. Transactions of the Royal Society of Edinburgh: Earth Sciences, 75, 189191.

Stone, P. 2014. A review of geological origins and relationships in the Ballantrae Complex, SW Scotland. Scottish Journal of Geology, 50, 1-25.

Stone, P. \& Rushton, A.W.A. 1983. Graptolite faunas from the Ballantrae ophiolite complex and their structural implications. Scottish Journal of Geology, 19, 297-310.

Stone, P. \& Rushton, A.W.A. 2003. A Late Arenig (early Yapeenian) graptolite fauna and the coeval tectonic development of the Ballantrae Complex, SW Scotland.

Scottish Journal of Geology, 39, 29-40.

Stone, P. \& Smellie, J.L. 1988. The Ballantrae area: a description of the solid geology of parts of 1:25 000 sheets NX08, 18 and 19. Classical areas of British Geology. HMSO for British Geological Survey.

Stone, P. \& Strachan, I. 1981. A fossiliferous borehole section within the Ballantrae ophiolite. Nature, London, 293, 455-456.

Tanner, P.W.G. 2014. A kinematic model for the Grampian Orogeny, Scotland. In: Corfu, F., Gasser, D. \& Chew, D.M. (eds). New Perspectives on the Caledonides of Scandinavia and Related Areas. Geological Society, London, Special Publication.

390, 467-511.

Thirlwall, M.F. \& Bluck, B.J. 1984. Sr-Nd isotope and geological evidence that the Ballantrae "ophiolite", SW Scotland, is polygenetic. In: Gass, I.G., Lippard, S.J. and Shelton, A.W. (eds.), Ophiolites and oceanic lithosphere. Geological Society, London, Special Publication. 13, 215-230. 
Treloar, P.J., Bluck, B.J., Bowes, D.R. \& Dudek, A. 1980. Hornblende-garnet metapyroxenite beneath serpentinite in the Ballantrae complex of SW Scotland and its bearing on the depth provenance of obducted oceanic lithosphere. Transactions of the Royal Society of Edinburgh: Earth Sciences, 71, 201-212.

VandenBerg, A. H. M. 2017. Revision of zonal and related graptolites of the topmost Lancefieldian and Bendigonian (Early Floian) graptolite sequence in Victoria, Australia. Proceedings of the Royal Society of Victoria, 129, 39-74.

VandenBerg, A. H. M., \& Cooper, R. A. 1992. The Ordovician graptolite sequence of Australasia. Alcheringa, 16, 33-85.

Williams, A. 1962. The Barr and Lower Ardmillan Series (Caradoc) of the Girvan district of south-west Ayrshire, with descriptions of the brachiopoda. Geological Society, London, Memoir 3.

Table 1

\begin{tabular}{|l|l|l|l|l|l|}
\hline Age & Method & Authors & & Source & Location \\
\hline $\begin{array}{l}483 \pm 4 \\
\mathrm{Ma}\end{array}$ & U-Pb & $\begin{array}{l}\text { Bluck } \text { et al. } \\
1980\end{array}$ & & $\begin{array}{l}\text { Zircon in } \\
\text { leucotonalite }\end{array}$ & Byne Hill \\
\hline $\begin{array}{l}478 \pm 8 \\
\mathrm{Ma}\end{array}$ & $\mathrm{K}-\mathrm{Ar}$ & $\begin{array}{l}\text { Bluck } \text { et al. } \\
1980\end{array}$ & $\begin{array}{l}\text { Hornblende in } \\
\text { amphibolite }\end{array}$ & Knocklaugh \\
\hline $\begin{array}{l}487 \pm 8 \\
\mathrm{Ma}\end{array}$ & $\mathrm{K}-\mathrm{Ar}$ & $\begin{array}{l}\text { Bluck } \text { et al. } \\
1980\end{array}$ & & Gabbro & Millenderdale \\
\hline $\begin{array}{l}501 \pm 12 \\
\mathrm{Ma}\end{array}$ & $\mathrm{Sm}-\mathrm{Nd}$ & $\begin{array}{l}\text { Thirlwall \& } \\
\text { Bluck 1984 }\end{array}$ & & $\begin{array}{l}\text { Island arc } \\
\text { basalt }\end{array}$ & Mains Hill \\
\hline $\begin{array}{l}476 \pm 14 \\
\mathrm{Ma}\end{array}$ & $\mathrm{Sm}-\mathrm{Nd}$ & $\begin{array}{l}\text { Thirlwall \& } \\
\text { Bluck 1984 }\end{array}$ & & $\begin{array}{l}\text { Island arc } \\
\text { basalt }\end{array}$ & Games Loup \\
\hline $\begin{array}{l}470 \pm 10 \\
\mathrm{Ma}\end{array}$ & $\mathrm{U}-\mathrm{Pb}$ & $\begin{array}{l}\text { Sawaki } \text { et al. } \\
2010\end{array}$ & & Zircon in tuff & Bennane Lea \\
\hline $\begin{array}{l}477.6 \pm \\
1.9 \mathrm{Ma}\end{array}$ & Sm-Nd & $\begin{array}{l}\text { Stewart } \text { et al. } \\
2017\end{array}$ & & $\begin{array}{l}\text { Garnet in } \\
\text { amphibolite }\end{array}$ & Knocklaugh \\
\hline
\end{tabular}

Table 1. The archive of radiometric dates relevant to the age of the Balcreuchan Group, Ballantrae Complex. Other recent results from Bennane Lea presented by Fujisaki et al. (2015) are discussed in detail elsewhere in this paper. 
Figures 1-4

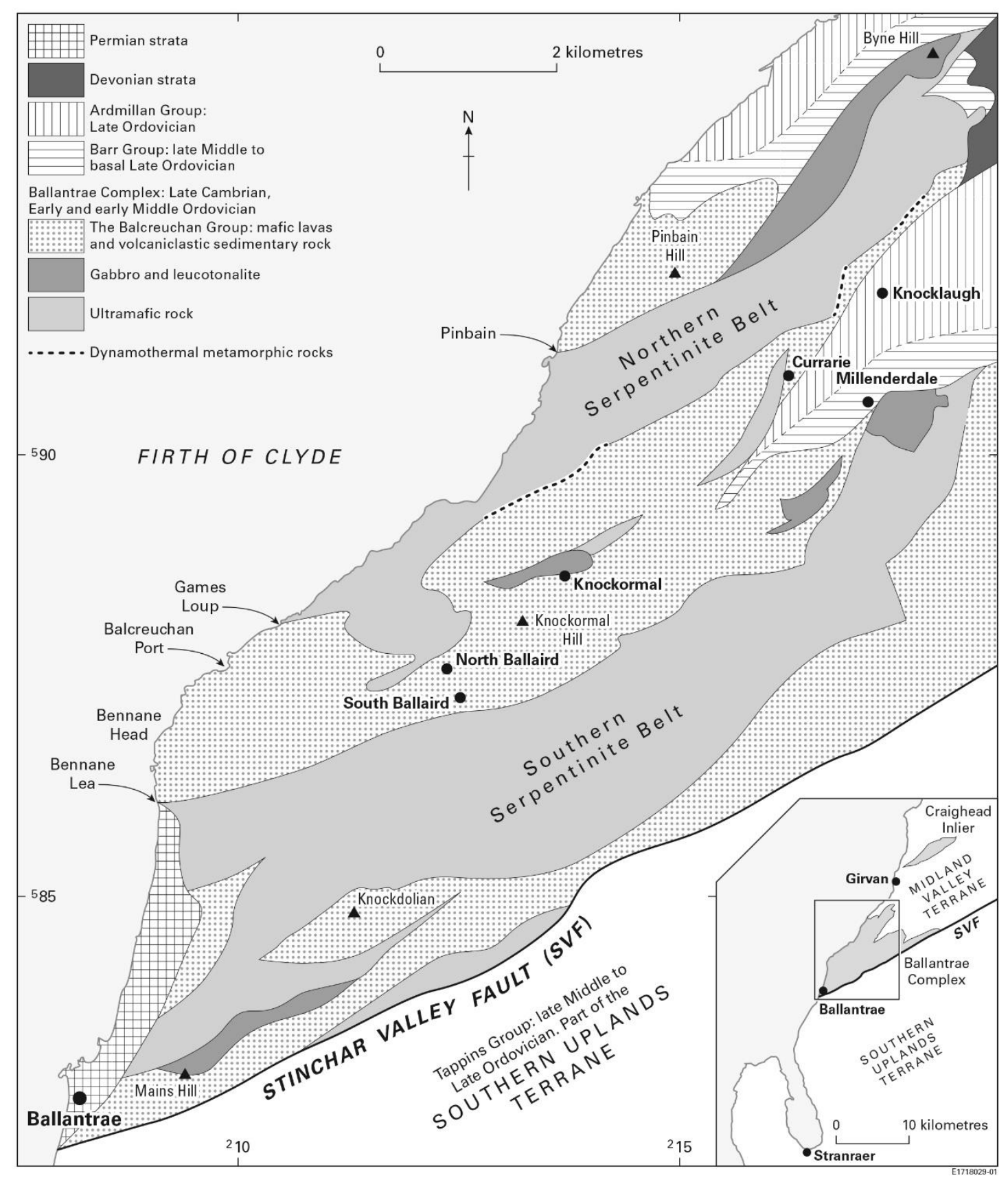

Figure 1. The position of the Ballantrae Complex in SW Scotland and the outline geology of its south-western part, after Stone \& Smellie (1988). 


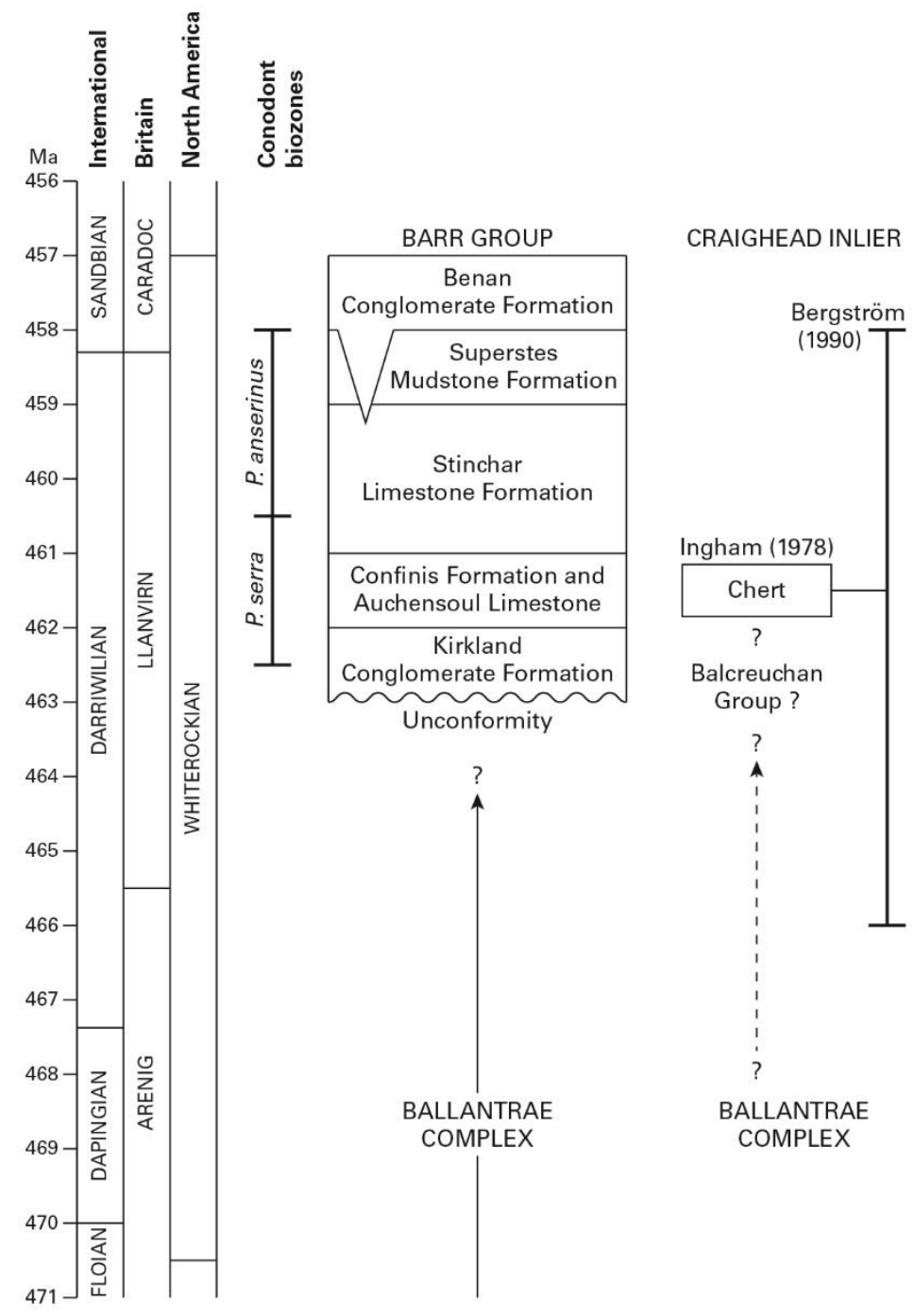

Figure 2. Stratigraphic sections for the late Middle Ordovician Barr Group after Ingham (2000), and the lowermost part of the Craighead Inlier succession showing the alternative interpretations of Ingham (1978) and Bergström (1990), Time scale after Cooper \& Sadler (2012). 


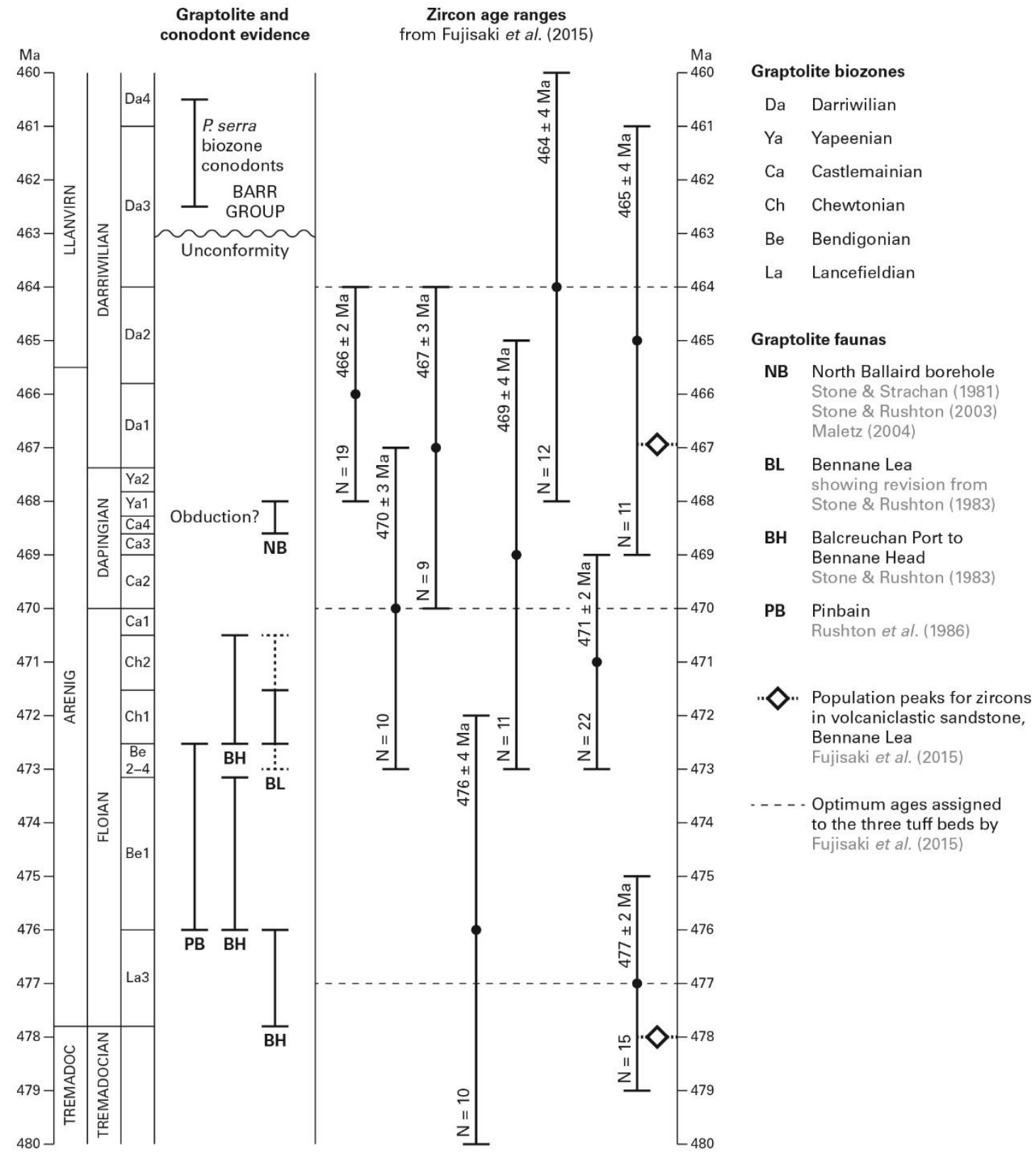

Figure 3. An age range chart summarising the biostratigraphic evidence from the Balcreuchan Group and the volcanogenic zircon dating results from its Bennane Lea section. Chronostratigraphic correlations after Bergström et al. (2008). Time scale after Cooper \& Sadler (2012). 


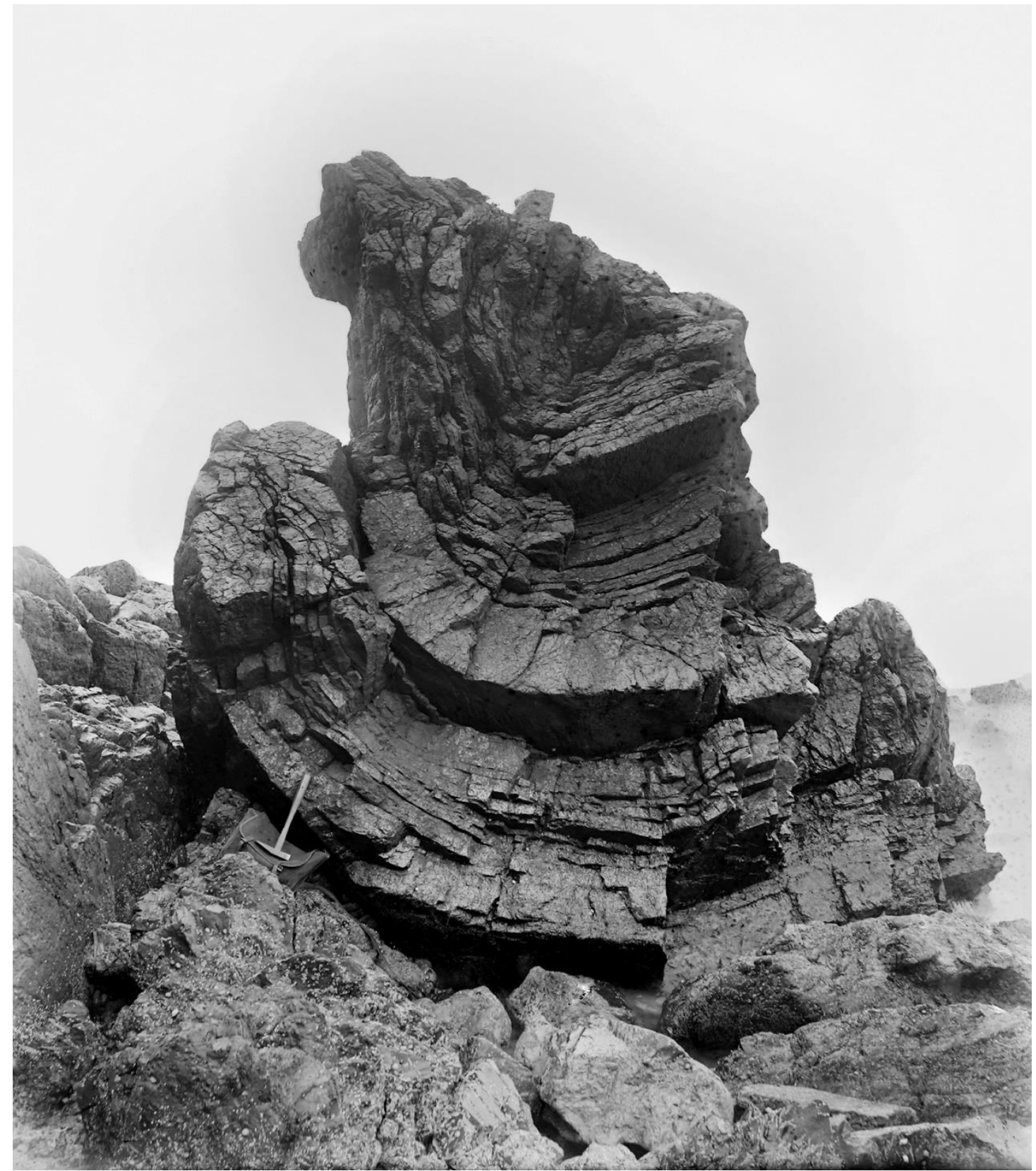

Figure 4. Folding of the chert succession at Bennane Lea; the fold hinge, one of a series, plunges moderately to the west, away from the observer. Illustration from Peach \& Horne (1899, plate 7). BGS image P215180. 
